\title{
A Social History of Early Rock ' $n$ ' Roll in Germany: Hamburg from Burlesque to the Beatles,
}

1956-69, by Julia Sneeringer, London, Bloomsbury Academic, 2018, 289pp. $£ 85.00$ (hardback), ISBN: 9781350034389

The German city of Hamburg and more particularly the St Pauli district holds a special place in the historiography of British popular music. It forms a core foundation myth in the story of the Beatles and the transnational impact of rock ' $n$ ' roll. Yet to date there has been no detailed, analytical history of the city, which explores the vibrancy, soundscapes and sociology of the developing the sound, style and subcultures that were a feature of its postwar development. This book does so much more than add to the voluminous literature on the Beatles and is a further example of the ways in which historians are increasingly turning to studies of popular music that once were the preserve of sociologists and cultural theorists. As a skilled historian, Sneeringer has produced a finely grained social history that draws on a multiplicity of primary sources and oral testimonies in recreating the voices, sounds, spaces, and characters that were at the forefront of St Pauli's music scene.

St Pauli is not just explored as a site of music making, but is reconstructed by the author as 'a field of cultural exchange ... across lines of nation, class, gender and race' (p.2). The text is bookended by chapters that chart in detail the development of the district as a locale of drink, sex, music and hedonism that reflected broader structural and cultural changes linked to capitalist development, migration, consumption and shifting social identities. The first chapter presents a fascinating history of pre-war St Pauli and the variety of types including entrepreneurs, prostitutes, migrants and German youths who were drawn to the danger and exoticism of its bars, brothels and boudoirs. Under Nazi rule and after, it remained a place where people could subvert social norms and participate in everyday acts of formal 
and informal resistance. Such activities were soundtracked by jazz, swing, blues, rock ' $n$ ' roll, and St Pauli 'served as a foil to dominant notions of national identity' (p. 44).

The arrival of rock ' $n$ ' roll in its 'year zero' of 1956 represented a moment where the past and present clashed in the bars, clubs and streets of St Pauli. German youths, British and American musicians, were all making sense of their own place in Western society in the aftermath of war. We are introduced here to a diverse cast of characters many of whom were motivated by entrepreneurial zeal and profit in exploiting the growing affluence of youth. The author takes us into the audience and backstage at seminal venues such as the Top Ten, the Kaiserkeller and Star Club. The first two chapters are detailed and analytical, but largely fail to engage with the recent revisionist perspectives relating to the connection between youth, popular music and class. However, the following three substantive chapters on musicians, fans and audiences, and the authorities, are underpinned by the use of a range of primary sources and methodological approaches that are notable for their originality. Opening in 1962 the iconic Star Club initially attracted a working-class clientele that embraced the 'beat music' of America and Britain. The author uses then contemporary texts such as the Star Club News to show that fans appeared in the publication 'not as passive consumers but active shapers of the scene' (p. 114).

Significant space is devoted to the experiences of female musicians such as The Liverbirds and the ways in which teenage girls consumed music and engaged with the night-time economy of the district. More generally, there is an exploration of how German 'beat fans' constituted a sense of self through music. This was sometimes used as a form of cultural capital to create subcultural diversity and 'distance from a tainted German identity' (p. 104). In contrast to some of standard narratives of the transformative power of rock ' $n$ ' roll, 
Sneeringer focusses on the role music played in the mundane practices of everdaylife in homes and bedrooms. The Beat clubs were also 'a site of love and friendship ... emotions generated by music and dancing were intertwined with feelings for the people with whom they shared their experiences' (pp. 110-111). As in Britain and America, Germany was not immune to the 'moral panics' that were generated by rock ' $n$ ' roll and these are critically explored with some expertise through police and legal records.

Like London, Liverpool, New Orleans, Chicago, New York, Detroit, Memphis and Nashville, Hamburg now has its own place on maps of the history of popular music. The author critically examines St Pauli's rise, fall and rise again reflecting on the processes that have grounded rock ' $n$ ' roll in the social history of the United States and Europe. The demolition of the Star Club preserved its place in the collective memory of German youths who came of age in the 1960s and St Pauli is now a stop on the pilgrimages of generations of Beatles fans. Sneeringer has produced an intellectually engaging and very readable book that examines the everyday realities, experiences, dreams and mythologies of a city that held its own particular histories, mysteries, secrets and soundscapes in the personal narratives of postwar popular music.

Keith Gildart (keith.gildart@wlv.ac.uk) is Professor of Labour and Social History in the Centre for Historical Research, University of Wolverhampton. He is the author of Images of England through Popular Music: Class, Youth and Rock ' $n$ ' Roll, 1955-1976 (Palgrave Macmillan, 2013). 